\title{
Prilagoditev učiteljev pri poučevanju glasbene umetnosti ob spremembi učnega okolja spomladi 2020
}

\author{
Matija Jenko \\ Univerza na Primorskem \\ matija.jenko@pef.upr.si \\ Barbara Kopačin
Univerza na Primorskem
barbara.kopacin@pef.upr.si
}

Svet se je od lanskega marca v marsičem zelo spremenil. Pogosteje kot kadar koli prej delamo, se izobražujemo ... s pomočjo interneta. Tudi poučevanje glasbene umetnosti se je čez noč preselilo na internet v domače učno okolje učiteljev in učencev. Specifičnost predmeta glasbena umetnost predstavljajo predvsem glasbene dejavnosti in z izvajanjem le-teh pridobivanje tako glasbenih znanj kot tudi sposobnosti in spretnosti. Zanimalo nas je, kako so učitelji glasbene umetnosti v prvem in drugem vzgojno-izobraževalnem obdobju osnovne šole videli prehod iz učnega okolja v učilnici v učno okolje učenčevega in učiteljevega doma s pomočjo IKT. Zanimalo nas je tudi, kako so ob tej selitvi spremenili svoj način dela zaradi specifik predmeta glasbena umetnost (poslušanje, izvajanje in ustvarjanje). Ugotavljamo, da je prehod iz šolskega v domače učno okolje veliko učiteljev ujel nepripravljenih, kar je za seboj potegnilo veliko težav, ki so jih učitelji zaznali zelo različno. Prav tako so ti morali svoj način poučevanja glasbene umetnosti prilagoditi spremenjeni situaciji.

Ključne besede: glasbena umetnost, glasbene dejavnosti, poučevanje na daljavo, sprememba učnega okolja, IKT

\section{Uvod}

Z izdajo Odredbe o razglasitvi epidemije nalezljive bolezni covid-19, ki jo povzroča koronavirus SARS-CoV-2 na območju Republike Slovenije (2020), se je 16. marca 2020 prvič v zgodovini zgodilo, da se je učno okolje iz šolskih klopi po internetu preselilo na domove učencev. Zaradi tega ukrepa so morali učitelji pedagoški proces $v$ trenutku začeti izvajati s pomočjo interneta, tako z izvedbo predavanj na daljavo kot s pripravo gradiv za delo doma. Potrebna je bila tudi prilagoditev pouka glasbene umetnosti, kar predstavlja svojevrsten izziv, saj dejavnosti le-te obsegajo tri področja: izvajanje (petje, igranje na glasbila in ritmično izrekanje), ustvarjanje in poslušanje glasbe. Skozi tri pod- 
ročja glasbenih dejavnosti otroci pridobijo tudi glasbena znanja (Ministrstvo za šolstvo in šport 2011). Vsak učitelj je imel tako po prvi razglasitvi epidemije pri poučevanju na daljavo prosto izbiro sredstev pri pripravi učnega okolja na domovih učencev (Ministrstvo za izobraževanje, znanost in šport 2020; Sklep o ukrepih za nemoteno opravljanje vzgojno-izobraževalnega dela v osnovnih šolah v šolskem letu 2019/2020 2020), zato se ga je vsak lotil na svoj način. V prispevku nas zanima, kako so učitelji, ki poučujejo glasbeno umetnost, v trenutku prešli iz šolskega v domače učno okolje, kako so se lotevali poučevanja glasbene umetnosti na daljavo ter kakšna gradiva so pripravljali učencem za delo doma.

Nezanemarljivo je po našem mnenju tudi dejstvo, da imajo učitelji doma različno računalniško opremo in gradiva ter nenazadnje tudi ustvarjalnost in znanje za uporabo informacijsko-komunikacijske tehnologije ( $v$ nadaljevanju IKT) ter izdelavo učnih gradiv.

\section{Pouk glasbene umetnosti}

Predmet glasbena umetnost se poučuje po Učnem načrtu za glasbeno vzgojo (Ministrstvo za šolstvo in šport 2011). V prvem vzgojno-izobraževalnem obdobju je za vsako šolsko leto $v$ učnem načrtu predvidenih 70 ur glasbene umetnosti, $v$ četrtem in petem razredu pa 52 ur in pol. Učni načrt vključuje tudi opis možnih medpredmetnih povezav, poglavje o preverjanju in ocenjevanju znanja, o IKT pri pouku ter o domačih nalogah.

Kot tudi danes ugotavljajo različni avtorji (Pesek 1997), je zelo priporočljivo, da se glasbena umetnost v pouk uvede že zelo zgodaj, saj je pomembno, da otroka skozi uporabo različnih glasbenih dejavnosti, kot so petje, igranje na glasbila, poslušanje, ustvarjanje glasbe ter izvajanje glasbenih iger, glasbeno oblikujemo že od malega. Pri načrtovanju pedagoškega dela pri omenjenem predmetu je zato zelo pomembno, da učitelj izbere ustrezne oblike in metode dela, da glasbeno umetnost tudi medpredmetno povezuje $z$ drugimi predmeti ter tudi da pozna razvojne značilnosti otrok, ki jih uči, saj lahko le na ta način zahtevnost glasbenih dejavnosti prilagaja njihovima sposobnosti in zmogljivosti (Marjanovič Umek 2004). Z daljšanjem delovne dobe si učitelj pridobiva izkušnje, s tem pa njegova usposobljenost za poučevanje raste (Jekovec 2011; Holden in Button 2006). Nekateri učitelji so se v mladosti ali pa se še danes udejstvujejo $v$ različnih glasbenih dejavnostih, lahko pojejo $v$ pevskem zboru ali pa le-tega na šoli celo vodijo, zanje pa Jenko (2019) in Slosar (1997) ugotavljata, da njihove izkušnje skupaj s tistimi, ki jih morebiti pridobijo v glasbeni šoli ali pri kateri koli drugi obliki glasbenega udejstvovanja, pomembno vplivajo tudi na njihovo sposobnost poučevanja predmeta glas- 
bena umetnost. Sicer pa temeljne metode glasbenega učenja in poučevanja uresničujemo skozi glasbene dejavnosti (Borota 2013; Ministrstvo za šolstvo in šport 2011).

V letu 2020 se je vsa praksa, ki so se je učitelji pri predmetu glasbena umetnost posluževali do takrat, na hitro zelo spremenila, kar pa je v nasprotju z Bečajevo (2008) trditvijo, da je spreminjanje šolskega okolja dolgotrajen proces. Avtor namreč trdi, da se šolsko okolje in šolska kultura predvsem na našem geografskem področju spreminjata zelo počasi. To pripisuje tudi precejšnji tradicionalnosti v slovenskih šolah, kjer se učitelji še vedno čutijo večinsko odgovorne za dosežke in učne uspehe svojih učencev, prav tako so glavni usmerjevalci dejavnosti, ki jim učenci sledijo. Učitelji se večinoma poslužujejo frontalne oblike poučevanja, njihovo uspešnost pa se meri predvsem po učnem uspehu njihovih učencev. Vse to pa je bilo z začetkom epidemije postavljeno pod velik vprašaj, saj se je s spremembo učnega okolja spremenil tudi pogled na marsikateri vidik poučevanja.

Predmet glasbena umetnost se sicer poučuje skozi glasbene dejavnosti, ki jih Denčeva (2002) opisuje kot samostojno obliko glasbenega izražanja. Skozi te dejavnosti pri učencih vzbujamo veselje do glasbe, gibanja in nenazadnje do igre, ki je velikokrat spremljevalna aktivnost pri primarnih, z glasbo povezanih dejavnostih. $V$ zadnjih desetletjih se vloga učitelja iz edinega vira informacij (Kerndl 2010) spreminja predvsem v svetovalca, usmerjevalca, poslušalca, inštruktorja, vodnika, moderatorja, organizatorja ... in opazovalca, ki lahko učni proces fleksibilno prilagaja zmožnostim, potrebam in interesom učencev. Ob nenadni spremembi učnega okolja spomladi 2020 je moral učitelj za izvajanje glasbenih dejavnosti, kot jih opredeljuje Peskova (1997), torej petje pesmi, poslušanje glasbe, igranje na glasbila, gibanje ob glasbi (ples), usvajanje glasbenih pojmov ter glasbena ustvarjalnost, ustvariti prej opisano učno okolje in uporabiti aktivne metode in strategije, ki niso smele postati same sebi namen in so tako optimalno pripeljale do zastavljenih izobraževalnih, funkcionalnih ter vzgojnih ciljev (Kerndl 2010). Učenci prav skozi te dejavnosti, ki jih po Peskovi (1997) lahko združimo v poslušanje, izvajanje in ustvarjanje, ustvarjajo nove možganske povezave, kar jih vodi v razmišljanje in reševanje (glasbenih) problemov ter organizacijo zaznav, primerjav ter ustvarjanja novih pojmov. Ob petju in poslušanju glasbe otrok pridobiva tudi besedni zaklad, pri igranju glasbil in ritmičnem gibanju pa povečuje nadzor nad svojim telesom.

Morijeva s sodelavci (2003) in Sicherl Kafolova (2015) trdijo, da mora biti med osnovnošolskim izobraževanjem otrokom nuden predvsem kakovosten pouk glasbene umetnosti, saj se tako celostno razvijejo (spoznavni, 
čustveno-socialni in telesno-gibalni razvoj). Za izvajanje kakovostnega pouka pa morajo učitelji, ki glasbeno umetnost poučujejo, poleg zelo dobrega poznavanja učnih ciljev poznati tudi metode, s katerimi jih dosežejo, kjer pa bo dovolj pozornosti posvečene tudi refleksiji, presoji, odzivu in sodbi mladega človeka (Kerndl 2010). K načrtovanju je tako po Denčevi (2002) potrebno pristopiti sistematično in predvsem upoštevati pestrost ter raznolikost dejavnosti, ki jih ima učitelj na voljo za dosego ciljev. Predvsem pa bi morali učitelji sprejeti nove vloge (Kerndl 2010), kot je odprtost za spreminjanje in vključevanje novih IKT $\vee$ pouk, in jih prilagoditi novim okoliščinam in situacijam ter opustiti ali spremeniti tradicionalno vlogo posredovalca znanja v vlogo organizatorja učnih okolij in situacij.

Glasbene dejavnosti, ki jih učitelj izvaja v razredu, so le delčki mozaika, ki ga učencem skozi spodbudno ter varno učno okolje ponudi učitelj. Prav slednje po različnih raziskavah (Dumont, Istance, in Benavides 2013) pri učencih pušča ugodne posledice, kot so boljši učni dosežki, vključenost, zagotavljanje možnosti za učenje itd. Prav gotovo pa lahko tudi z ustreznim in smiselnim izvajanjem glasbenih dejavnosti zagotovimo šolsko kulturo in klimo, ki ju lahko razumemo kot za učenje spodbudno, pozitivno, zdravo, odprto in varno učno okolje (Kranjc idr. 2019).

\section{Učenje na daljavo}

Učenje na daljavo je oblika izobraževanja, za katero je značilno, da sta učitelj in učenec na različnih lokacijah oz. fizično ločena, sam izobraževalni proces, ki ga organizira izobraževalna institucija, pa poteka s pomočjo različnih medijev z možnostjo dvosmerne komunikacije in občasnih študijskih srečanj (Keegan 1996). Kljub temu pa Toselli (2020) trdi, da si učitelj in učenec $v$ času izobraževanja na daljavo še nikoli nista bila tako blizu, saj učitelj posameznika doseže preko slušalke ali zvočnika, s čimer mu daje občutek, da govori samo z njim. Moore in Kearsley (2012) zaradi dejstva, da je učenje na daljavo bolj prilagojeno učencem kot učiteljem, raje uporabljata izraz izobraževanje na daljavo. V Sloveniji je sicer uveljavljen pojem »e-izobraževanje«, ki po nekaterih avtorjih (Lesjak, Sulčič in Trunk Širca 2005) pomeni širši pojem, vezan na izobraževalno institucijo, ki organizira izobraževanje, medtem ko je »eučenje«, kar je dobeseden prevod angleškega izraza e-learning, vezano le na aktivnost učečega se posameznika. E-izobraževanje naj bi bilo naslednji korak $v$ razvoju izobraževanja, $v$ katerem naj bi se vse dejavnosti, povezane $s$ tem, preselile na internet.

Pred leti je Mekić (2006) ugotavljal, da gre v osnovnošolskem okolju pri uporabi izraza e-izobraževanje predvsem za dostop učencev in učiteljev do 
e-gradiv, zunanjih knjižnic in v manjši meri tudi za prilagojen način dela za slabše in boljše učence ter da uporaba le e-izobraževanja za osnovno šolo ni najprimernejša, saj je za razvoj učencev zelo pomembno fizično okolje s sovrstniki v šoli in oseben pristop učiteljev do njih. Spomladi 2020 pa so v zelo kratkem času tako učitelji kot učenci morali poseči po različni IKT, čeprav Toselli (2020) opozarja, da pri poučevanju na daljavo tehnologije učencem ne smemo vsiljevati, temveč jo uporabimo takrat, ko smo prepričani, da jo znajo uporabljati. IKT je potrebno uporabljati premišljeno in postopoma, pri čemer bi morali vključevati tudi druga tradicionalna učna sredstva in pripomočke. $V$ letu 2020 je kot najpogostejše metode in oblike izobraževanja Toselli (2020) izpostavil videokonference in izvedbo kontaktnih ur na daljavo $v$ živo, platforme za poučevanje na daljavo, socialna omrežja in oblikovanje skupin za dopisovanje, elektronsko pošto, skupne dokumente v oblaku, avdio- in videoposnetke, videokanale in spletne strani.

\section{Platforme za učenje na daljavo v slovenskih osnovnih šolah}

V Sloveniji je na voljo kar nekaj ponudnikov, ki osnovnim šolam nudijo storitve informacijskega sistema, na katerih šola gostuje. $V$ nadaljevanju bomo predstavili le nekaj najpogostejših, ki se za tak način izobraževanja, poleg uradnih spletnih strani šol in ponudnikov e-pošte, uporabljajo.

Arnes ali Akademska raziskovalna mreža Slovenije (http://www.arnes.si) je javni zavod, ki šolam zagotavlja storitve s področja raziskovanja, izobraževanja in kulture ter na drugi strani omogoča njihovo povezovanje in sodelovanje s sorodnimi organizacijami v tujini. Arnes ni spletno mesto, ki bi ga učitelj neposredno uporabljal za potek izobraževanja na daljavo, temveč je bolj ponudnik storitev, ki to omogoča na sistemski ravni. V letu 2020 je po izbruhu virusa SARS-CoV-2 pridobil finančno podporo za program »COVID19 - dodatna podporna IKT za izvajanje vzgojno-izobraževalnega procesa«. Program je sicer spadal pod okrilje Ministrstva za izobraževanje, znanost in šport ( $v$ nadaljevanju MIZŠ) in je bil za zavode, ki so bili s strani Vlade Republike Slovenije izbrani za sodelovanje, financiran iz Evropskega sklada za regionalni razvoj. Namen programa, ki ga je izvajal Arnes, je zagotovitev IKT-infrastrukture kot osnove za izobraževanje na daljavo. Cilj naložbe je bil na eni strani večkratno povečanje zmogljivosti Arnesovih storitev, kot so Arnes Učilnice, Arnes Splet, Arnes ePošta, Arnesove videokonferenčne storitve idr., po drugi strani pa z nakupom IKT tistim učencem, dijakom in učiteljem, ki v času razglasitve epidemije niso imeli ustrezne računalniške opreme ali finančnih sredstev za zagotovitev le-te, omogočiti učenje in poučevanje na daljavo (Zavod Arnes b. I.). eAsistent (https://www.easistent.com) je sistem, ki ga v Sloveniji trenu- 
tno uporablja vseh 454 osnovnih šol. Pokriva vse ključne procese na šoli z namenom nadgraditve sistema izobraževanja in zajema več kot 30 področij dela ter omogoča uporabo 137 različnih dokumentov - od e-redovalnice, e-dnevnika in dokumentov za razredništvo do komunikacije $s$ starši in evidence delovnega časa. Poleg naštetega nudi tudi t. i. oblačno platformo za dvosmerno nalaganje dokumentov, kjer lahko učitelji učencem nalagajo naloge, ti pa jih rešene oddajo nazaj v pregled. Učitelji ocene učencev beležijo $v$ e-redovalnico, ki je vedno na vpogled tudi staršem. Tako učitelji kot tudi učenci in njihovi starši imajo $v$ sistemu eAsistent vedno viden urnik in učenčeve (opravičene in neopravičene) izostanke. $V$ aplikaciji imajo učenci napovedana vsa preverjanja in ocenjevanja znanja, ki jih v sistem vpiše učitelj. Ta v sistem vpisuje še domače naloge, ki jih mora učenec narediti, temu pa se prikaže tudi pregled opravljenih ter neopravljenih nalog.

Lo.Polis (https://www.lopolis.si) v smislu vodenja šolske dokumentacije in komunikacije starš - učitelj - učenec nudi manj možnosti kot eAsistent, nudi pa tudi nekaj takih, ki jih prej opisana aplikacija ne omogoča. Nekatere funkcije Lo.Polisa so v svojem bistvu zelo podobne tistim, ki jih nudi eAsistent. Taki sta npr. e-redovalnica in e-sporočila, s tem da je druga storitev staršem na voljo proti plačilu, e-redovalnica pa je brezplačna. Poseben zavihek na portalu je namenjen učencem in dijakom, saj tam lahko s svojim uporabniškim imenom in geslom preverijo nadomeščanja, prihajajoče dogodke in ocenjevanja.

Moodle (https://moodle.org) je za razliko od eAsistenta in Lo.Polisa platforma, ki šolam ne nudi administrativno-informacijske podpore, je pa orodje, ki se ga učitelji lahko poslužujejo za izvedbo poučevanja na daljavo preko tako imenovanih e-učilnic. Jenko in Kočevar (2019) ugotavljata, da platforma predstavlja odprtokodni sistem za postavljanje spletnih učilnic, ki je prostodostopen, namenjen ustvarjanju učnih okolij, preverjanju in ocenjevanju znanj ter izmenjavi in bogatenju znanj ter izkušenj, zanj pa se lahko odločijo tako osnovne in srednje šole kot tudi univerze in drug zavodi. V Moodlu sicer vsak uporabnik lahko z različnimi funkcijami uredi svoje »okno« za interakcijo z ostalimi udeleženci.

Zoom (https://zoom.us), Skype (https://www.skype.com) ter tudi Microsoft Teams (https://www.microsoft.com/sl-si/microsoft-teams/group-chat -software) spadajo med videokonferenčne sisteme. Videokonference so sistemi vizualne komunikacije, ki omogočajo avdiovizualno in podatkovno povezavo uporabnikov, ki so fizično ločeni. Preko njih potekajo interaktivna srečanja, zato imajo široko uporabnost. V zadnjih letih po Grabnerjevi (2011) postajajo pomemben učni pripomoček za študente, MIZŠ pa jih je $v$ svo- 
jih »Priporočilih šolam za izvajanje izobraževanja na daljavo« (Ministrstvo za izobraževanje, znanost in šport 2020) priporočilo tudi za uporabo v osnovnih šolah. Preko njih lahko učenci učnim uram sledijo kar od doma. Prenos podatkov za videokonference poteka po internetu. Če želimo, da sta slika in zvok, še posebej ob večjem številu udeležencev, npr. celega razreda na predavanju, kakovostna, so videokonference tudi podatkovno zelo požrešne. Poleg računalnika, pametnega telefona ali tabličnega računalnika, ki ga potrebujemo za uporabo e-učilnic, za uporabo videokonferenčnih sistemov potrebujemo tudi zvočnike oz. slušalke, mikrofon ter kamero (Grabner 2011).

Vsi trije omenjeni sistemi so na voljo brezplačno, le da imata Zoom in Microsoft Teams na voljo osnovno in plačljivo različico. Skype v svoji edini (brezplačni) različici ponuja videokonferenčne klice $z$ deljenjem datotek za neomejeno število udeležencev za neomejen čas.

\section{Problem, namen in cilji}

$\checkmark$ prispevku nas zanima, kako je po opažanjih učiteljev, ki poučujejo glasbeno umetnost v prvem in drugem vzgojno-izobraževalnem obdobju osnovne šole, potekal prehod iz učnega okolja $v$ učilnici v učno okolje učenčevega in učiteljevega doma s pomočjo IKT ter kako so se učitelji zaradi specifik predmeta glasbena umetnost (poslušanje, izvajanje in ustvarjanje) lotevali poučevanja le-tega ob spremembi učnega okolja v začetku epidemije covida-19.

Tako smo si glede na problem in namen raziskave zastavili raziskovalna cilja, ki sta: (C1) ugotoviti in analizirati, kako je, po opažanjih učiteljev, ki poučujejo glasbeno umetnost v prvem in drugem vzgojno-izobraževalnem obdobju osnovne šole, potekal prehod iz učnega okolja v učilnici v učno okolje učenčevega in učiteljevega doma s pomočjo IKT-ja, in ( $\left.\mathrm{C}_{2}\right)$ ugotoviti in analizirati, kako so se učitelji zaradi specifik predmeta glasbena umetnost (poslušanje, izvajanje in ustvarjanje) lotevali poučevanja le-tega ob spremembi učnega okolja v začetku epidemije covida-19. Iz njiju smo razvili raziskovalni vprašanji (RV1), kako je po opažanjih učiteljev izgledal prehod iz učnega okolja $v$ učilnici $v$ učno okolje učenčevega in učiteljevega doma s pomočjo IKT in (RV2) na kakšen način so se učitelji zaradi specifik predmeta glasbena umetnost (poslušanje, izvajanje in ustvarjanje) lotevali poučevanja le-tega ob spremembi učnega okolja v začetku epidemije covida-19.

\section{Metodologija}

Izvedli smo raziskavo z anketnim vprašalnikom z vprašanji odprtega tipa, pri katerih so bili sodelujoči v raziskavi pozvani k podajanju daljših odgovorov, iz katerih smo pridobili kvalitativne podatke. 
Anketni vprašalnik so reševali razredni učitelji ter profesorji glasbe - glasbeni pedagogi, ki poučujejo glasbeno umetnost v prvem ali drugem vzgojno-izobraževalnem obdobju osnovne šole. Naš raziskovalni vzorec vsebuje 54 rešenih vprašalnikov. V raziskavi je bilo od 54 sodelujočih 51 (94,44 \%) učiteljev po izobrazbi profesorjev razrednega pouka, trije (5,55\%) so bili profesorji glasbe - glasbeni pedagogi, od vseh sodelujočih pa je bilo 47 (87,04\%) žensk in $7(12,96 \%)$ moških, kar se sklada tudi s podatki Statističnega urada Republike Slovenije (2017), ki ugotavlja, da je bilo v šolskem letu 2019/2020 $\checkmark$ osnovnošolskem izobraževanju v Sloveniji med vsemi zaposlenimi moških $12,61 \%$.

Anketni vprašalnik je bil namenjen učiteljem, ki učijo glasbeno umetnost v prvem vzgojno-izobraževalnem obdobju ter četrtem in petem razredu osnovne šole. $V$ prvem delu anketnega vprašalnika smo pridobili vpogled $v$ demografske podatke raziskovalnega vzorca, nato pa smo od sodelujočih z odprtimi vprašanji izvedeli, kakšen je bil po njihovem mnenju prehod iz učnega okolja $v$ učilnici $v$ učno okolje učenčevega in učiteljevega doma $s$ pomočjo IKT. Izvedeli smo tudi, na katere načine so se učitelji zaradi specifik predmeta glasbena umetnost (poslušanje, izvajanje in ustvarjanje) lotevali poučevanja le-tega ob spremembi učnega okolja $v$ začetku epidemije covida-19.

Raziskava je bila opravljena med 7. 6. in 1. 7. 2020. Po elektronski pošti je bila poslana povezava do anketnega vprašalnika, ustvarjenega prek spletne platforme za anketiranje www.1ka.si, s prošnjo, naj ga odgovorni posredujejo učiteljem, ki poučujejo glasbeno umetnost v prvem in drugem vzgojnoizobraževalnem obdobju osnovne šole.

Podatke smo po zaključenem anketiranju pregledali in pri deskriptivni statistiki za interpretacijo podatkov uporabili tematske mreže ter jih ustrezno interpretirali. V vseh tematskih mrežah širši pravokotnik pomeni večje število odgovorov, zapisanih v njem.

\section{Rezultati in razprava}

\section{Prehod iz učnega okolja $v$ učilnici $v$ učno okolje učenčevega in učiteljevega doma s pomočjo IKT}

Prehod iz učnega okolja $v$ učilnici v učno okolje učenčevega in učiteljevega doma s pomočjo IKT je večino učiteljev ujel nepripravljenih, saj se je zgodil tako rekoč čez vikend. Od vseh udeleženih v pouku je zahteval hitro prilagoditev znanj, praks in materialov za delo, še posebej pri šolskih predmetih, kot so glasbena in likovna umetnost ter šport, kjer se učenci ne učijo le znanj, marveč tudi spretnosti. Nas je posebej zanimal ta prehod na poučevanje na 
Preglednica 1 Opažanja prehoda iz učnega okolja v učilnici v učno okolje učenčevega in učiteljevega doma s pomočjo IKT skozi oči učiteljev

Na kakšen način se učitelji v času poučevanja na daljavo lotevajo poučevanja glasbene umetnosti?

Snemanje video in zvočnih posnetkov s strani učitelja.

Uporaba portalov s pretočnimi video vsebinami.

Uporaba videokonferenčnih sistemov.

Predstavitve v programu Microsoft Office PowerPoint.

Uporaba neavtorskih zvočnih posnetkov.

Uporaba platform za e-učilnice.

Uporaba e-učbenikov in e-delovnih zvezkov.

Uporaba e-pošte.

Snemanje zvočnih in video posnetkov s strani učencev.

Uporaba kvizov.

Uporaba sistemov za karaoke.

daljavo pri predmetu glasbena umetnost, zato so učitelji na vprašanje, kakšna so njihova opažanja prehoda s »klasičnega« pouka v učilnici na poučevanje na daljavo pri predmetu glasbena umetnost odgovorili z zelo različnimi odgovori, ki smo jih glede na skupni imenovalec združili v tematsko mrežo, na kateri širši pravokotnik pomeni večje število istih odgovorov. Vsak učitelj je lahko podal več različnih odgovorov, skupaj jih je bilo podanih 96, predstavljeni pa so $v$ preglednici 1.

Največ učiteljev, to je 18 (18,75\%), je v svojem odgovoru poudarilo, da na začetku niso bili vajeni dela na daljavo, enako je veljalo tudi za učence. V zelo kratkem času so se morali prilagoditi, si priskrbeti IKT-opremo ter na svoje računalnike naložiti različne programe, ki so jih uporabljali pri poučevanju na daljavo. Izpostavili so tudi, da se je ta prilagojenost in navajenost na način dela na daljavo s pretekom časa pri obeh deležnikih procesa izboljševala, tako da so bili na koncu maja, tik pred začetkom vračanja v šole, na tako delo že povsem prilagojeni. To seveda pripisujemo sprotnemu pridobivanju izkušenj in znanj s področja tako IKT kot tudi prilagajanju učnih metod in gradiv takemu načinu dela.

Le dva učitelja manj $(16,66 \%)$ sta poudarila dejstvo, da je bilo pri prilagajanju novemu načinu dela pomemben dejavnik predznanje s področja dela z IKT. Iz lastne izkušnje so tisti, ki so dela z IKT bolj vajeni, povedali, da so se sami ob prehodu na šolanje na daljavo takemu načinu dela veliko lažje prilagodili kot njihovi rokovanja z moderno tehnologijo manj vešči sodelavci, čemur pritrjujejo Javrhova idr. (2018), ki ugotavljajo, da digitalno pismen po- 
sameznik pozna ter zna za svoje osebne potrebe in za delo uporabljati digitalne pripomočke (računalniki, pametni telefoni, spletna orodja in aplikacije idr.). Ti pripomočki mu delo precej olajšajo, saj lahko s pomočjo znanja o njihovi uporabi z njihovo pomočjo komunicira, išče informacije in izvaja različna opravila, razume pa tudi zakonitosti socialnega okolja in se $v$ njem tudi znajde. Ta znanja mora za uspešno izvedeno poučevanje od doma imeti tudi učitelj. Tudi tuji avtorji (Loewus 2021) digitalno pismenost opredeljujejo podobno, in sicer kot zmožnost uporabe in komunikacije skozi IKT za iskanje, vrednotenje, ustvarjanje in povezovanje različnih informacij skozi uporabo tehnoloških znanj ter kognitivnih procesov.

Enako število učiteljev ( $16,66 \%)$ je v svojih opažanjih prehoda zapisalo, da je bila motivacija učencev za delo na daljavo na začetku bistveno višja kot kasneje, ko je poučevanje na daljavo že nekaj časa potekalo. To se je po njihovem mnenju pokazalo bolj, kot se sicer kaže pri pouku v učilnici, ko je upad motivacije $s$ potekom šolskega leta oz. $z$ bližanjem konca le-tega vseeno možno zaznati, a nikakor s takšno intenziteto, kot se je to zgodilo v primeru uvedbe šolanja na daljavo. To se sklada tudi z ugotovitvami Krajnčeve (1982), ki ugotavlja, da se pri otrocih že na splošno pojavljajo velika nihanja $v$ ravni motivacije za delo oz. za izobraževanje, ta nihanja pa lahko močno spodbudijo zunanji dejavniki, kamor prištevamo tudi premik izobraževanja iz učilnic na daljavo. Pri tem so učenci izgubili nek spodbujevalec zunanje motivacije, o kateri govorimo takrat, kadar se posameznik ukvarja z neko dejavnostjo zaradi posledic, ki ji sledijo. Pri zunanji motivaciji so poudarjeni zunanji cilji, h katerim stremi določena aktivnost. Ta motivacija pa običajno ni trajna; če vir zunanje podkrepitve izgine, motivacija pade. In v primeru selitve pouka na daljavo je izginil za učence zelo pomemben vidik šole - socialni vidik, ki predstavlja vsakodnevno druženje, klepet in igro (Marentič Požarnik 2020).

$14(14,58 \%)$ učiteljev je dejalo, da so bili pomemben dejavnik pri zagotavljanju pogojev uspešnega dela pri prehodu iz šolskega v domače učno okolje različni šolski skladi in drugi donatorji sredstev za IKT-opremo učencev, saj je prvi val epidemije povzročil nemalo presenečenja ob ugotovitvi, da veliko učencev ni opremljenih s potrebno IKT-opremo za izvedbo izobraževanja na daljavo (Uršič in Lotrič 2020). Potrebno se je zavedati, da si mnogi starši te opreme sami niso mogli privoščiti. V Republiki Sloveniji po podatkih Statističnega urada Republike Slovenije (b. I.) pod pragom revščine živi $12 \%$ vsega prebivalstva, $14.4 \%$ pa zaradi revščine tvega socialno izključenost. Prav navedeno je bil razlog, da je bilo $v$ trenutku selitve pouka na internet veliko učencev zaradi različnih dejavnikov (revščina, prepričanje staršev, geografska ne- 
pokritost z internetnim omrežjem idr.) nezmožnih takega načina dela. K rešitvi te težave so pripomogli različni donatorji, ki so najranljivejšim skupinam učencev poskušali zagotoviti najnujnejšo IKT-opremo ter jim tako omogočiti enake možnosti izobraževanja.

Da je bila izčrpanost na strani učiteljev zaradi večje porabe časa pri pripravi gradiv razlog, da so bili učitelji pri pripravi le-teh manj ustvarjalni, je menilo 11 $(11,46 \%)$ učiteljev. Poudarili so, da jim je za pripravo zanimivejših, inovativnejših in ustvarjalnejših učnih gradiv s posnetki sebe ob petju ob spremljavi glasbila in razlagi slikovnih zapisov glasbenih del preprosto zmanjkalo časa. Da učiteljem pri delu z IKT velikokrat primanjkuje časa, ugotavlja tudi Plazarjeva (2010); iz tega razloga so določene obravnave primorani okrniti ali celo opustiti. Iz odgovorov je bilo razbrati, da so učitelji zelo okrnili delo pri predmetu glasbena umetnost. Ustvarjanja ob glasbi in v glasbi sploh ni bilo. Učenci so se tako npr. z nekaj doma izdelanimi zvočili posneli ob spremljavi pesmi, ki so jih pred menjavo učnega okolja prepevali v šoli in posnetke poslali učiteljem. Ker so jim založbe omogočile poslušanje posnetkov preko spletnih strani učbenikov, so glasbo lahko tudi poslušali, novih pesmic pa so se ob teh posnetkih tudi naučili. Izvajanja na lastna glasbila kot ritmične spremljave naučenih pesmi skorajda ni bilo. Tudi zvočnih slik skupinsko niso mogli ustvarjati, saj je ob kontaktnih urah v živo preko videokonferenčnih sistemov prihajalo do zamika in je bil zato tak način dela nemogoč.

Enako število učiteljev (11,46\%) meni, da gradiva, ki so sicer pripravljena za uporabo z IKT, v osnovi niso namenjena delu na daljavo, kar je otežilo njihovo uporabo. $S$ tem so ciljali predvsem na e-učbenike in e-delovne zvezke, ki so med učitelji precej razširjeni, a so kljub temu, da so namenjeni uporabi preko različnih medijev (računalnikov, tablic, telefonov ter interaktivnih tabel), neprimerni za delo na daljavo. Tako so učitelji opazili tudi, da so velik del učnih ur porabili za reševanje težav, povezanih s samo uporabo teh gradiv (pomoč učencem pri dostopanju do njih ipd.).

Kot zadnje opažanje učiteljev o prehodu s »klasičnega« pouka na poučevanje na daljavo je bilo izpostavljeno, da je bilo predmete, ki vsebujejo učenje nekih spretnosti, precej težje prilagoditi poučevanju na daljavo kot tiste, ki vsebujejo le učenje znanj. Tu so izpostavili predmete glasbena in likovna umetnost ter šport. Pri teh predmetih gre pri »klasičnem« pouku za učenje spretnosti skozi različne skupinsko ali individualno izvedene dejavnosti v za to prilagojenem učnem okolju, česar pa učenci doma niso imeli. Večina od $11(11,46 \%)$ učiteljev, ki so to izpostavili, je napovedala tudi, da bodo imeli učenci ob vrnitvi pouka $v$ stare tirnice pri teh predmetih največji manko oz. celo upad nekaterih spretnosti in sposobnosti. 
Preglednica 2 Načini poučevanja glasbene umetnosti po selitvi pouka na internet

Kakšna so vaša opažanja prehoda iz »klasičnega« pouka v učilnici na poučevanje na daljavo?

Prilagojenost tako učiteljev kot učencev na tak način dela je bila premo sorazmerna s pretečenim časom.

Pomemben faktor pri prilagajanju novemu načinu dela je bilo predznanje s področja IKT oz. t. i. računalniška pismenost učiteljev.

Motivacija učencev za delo na daljavo je bila obratno sorazmerna s pretečenim časom.

Pomemben dejavnik pri zagotavljanju pogojev uspešnega dela so bili šolski skladi in drugi donatorji sredstev za IKT opremo učencev.

Izčrpanost na strani učiteljev je zaradi večje porabe časa pri pripravi gradiv pomenila manjšo mero ustvarjalnosti pri pripravi le-teh.

Gradiva, ki so sicer pripravljena za uporabo z IKT, v osnovi niso namenjena delu na daljavo, kar je otežilo njihovo uporabo učiteljem.

Predmete, ki vsebujejo učenje glasbenih spretnosti in sposobnosti, je bilo precej težje prilagoditi poučevanju na daljavo kot tiste, ki vsebujejo le učenje znanj.

\section{Poučevanje glasbene umetnosti na daljavo}

Iznajdljivost učiteljev se je ob spremembi učnega okolja ob začetku epidemije bolezni covid-19 hitro pokazala, saj so morali najti nove načine poučevanja pri vseh predmetih, tudi pri glasbeni umetnosti. Poučevanje tega predmeta je zaradi specifik (poslušanje, ustvarjanje in izvajanje) zelo kompleksno (Ministrstvo za šolstvo in šport 2011). Kot je razvidno iz preglednice 2, so zato učitelji na vprašanje, na kakšne načine so se takega poučevanja lotevali, odgovorili z zelo različnimi odgovori, ki smo jih glede na skupni imenovalec združili v tematsko mrežo, na kateri širši pravokotnik pomeni večje število istih odgovorov. Vsak učitelj je lahko podal več različnih odgovorov, skupaj jih je bilo podanih 122.

Da so se pri pouku zvočno in vizualno posneli ter kasneje posnetke na razne načine posredovali učencem, ki so si jih lahko ogledali takoj ali s časovnim zamikom, je odgovorilo največ učiteljev, to je 24 (19,67\%). Poleg avtorskih zvočnih in videozapisov so pri svojem delu učitelji uporabljali tudi različne portale s pretočnimi videovsebinami (YouTube, Vimeo idr.), učencem pa so poslali spletne povezave do njih. Največkrat so se posneli s pametnimi telefoni, da so učencem predstavili novo pesem, ki naj bi se jo le-ti z večkratnim poslušanjem naučili. Posnetke so potem pripeli na različne PowerPointove predstavitve. Izdelava videa je sicer zelo časovno potratna, če želi učitelj posneti kvaliteten izdelek. $V$ delovnem prostoru mora imeti mir in tišino, kar pa v času poučevanja na daljavo vsem učiteljev ni bilo zagotovljeno, saj so bili doma tudi njihovi družinski člani (Žugič Perić 2020).

Uporabo videokonferenčnih sistemov Zoom, Microsoft Teams in Skype je 
v odgovorih omenilo $18(14,75 \%)$ učiteljev. Preko njih so imeli z učenci kontaktne ure (predavanja) v živo. Omenili so, da je uporaba teh sistemov dobra zaradi omogočene dvosmerne komunikacije $z$ učenci $v$ času, ko so imeli na urniku dejansko predvidene ure glasbene umetnosti. Vambergerjeva (2020) trdi, da so bili učenci pri delu na daljavo najzadovoljnejši ravno z videokonferencami, saj so jim ponujale najboljšo razlago učne snovi. Vsekakor pa dejavnosti glasbene umetnosti niso mogli izvajati v živo zaradi zamika, do katerega prihaja pri prenosu podatkov preko interneta.

V programu Microsoft PowerPoint je svoje predavanja pripravilo 13,11\% učiteljev, ki so sodelovali v raziskavi, kar pomeni 16 oseb. Določeni učitelji so $v$ tem programu naredili le predstavitve določenih učnih tem, te pa so nato učenci doma obdelali sami. Drugi učitelji so omenili uporabo naprednejših funkcij programa, saj so z njim naredili interaktivne predstavitve, $v$ katere so integrirali tako avtorske zvočne in videoposnetke kot tudi posnetke, najdene na internetu. Craig in Amernic (2006) trdita, da bi morali učitelji, ki pri pouku uporabljajo predstavitve Microsoft PowerPoint, večji poudarek nameniti sodelovanju $z$ učenci pri oblikovanju učnih dejavnosti z uporabo tega programa, da bi učence s tem spodbujali, da bi z lastno participacijo pripomogli k optimizaciji predstavitev. Najpomembneje pa je, da bi morali učitelji razmisliti o dodani vrednosti, ki jo, poleg obravnave učne snovi, nudi uporaba programa. Skozi njegovo uporabo učenci spoznavajo tudi možnosti uporabe IKT ter razvijajo drugačen način mišljenja. Kot možnost nadgradnje uporabe programa so sodelujoči učitelji v naši raziskavi omenili še uporabo kvizov, preverjanj in vključitve zunanjih povezav do zanimivih tematik v samo predstavitev Microsoft PowerPoint.

Spomladi 2020 se je 15 (12,30 \%) učiteljev, ki so sodelovali v naši raziskavi, pri svojem delu posluževalo tudi e-učilnic (Moodle, LoPolis, eAsistent in Arnesovih aplikacij), preko katerih so učencem posredovali vsebine, ki so sicer zajete $v$ drugih odgovorih.

Enako število učiteljev $(12,30 \%)$ je pri poučevanju glasbene umetnosti na daljavo uporabljalo neavtorske zvočne posnetke. Kot primer takih posnetkov so navedli predvsem vnaprej posnete otroške pesmi in glasbene pravljice, ki so jih pošiljali. Uporabljali pa so tudi posnetke, ki jih imajo na spletnih straneh različnih založb, katerih učbenike uporabljajo pri svojem poučevanju.

Uporabo e-učbenikov in e-delovnih zvezkov je omenilo 12 (9,84\%) učiteljev. S pomočjo prvih so skupaj z učenci obdelali neko učno snov, druge pa so učenci uporabljali za utrjevanje. Prav vsi sodelujoči v raziskavi so, kljub več obstoječim potrjenim e-učbenikom in e-delovnim zvezkom različnih slovenskih založniških hiš, omenili le komplet Lilibi (Lili in Bine) ter Radovednih 5. 
J. Vraber Jagodic (2017) ugotavlja, da pri pouku v živo učitelji v večji meri uporabljajo tiskane učbenike in lastna pripravljena gradiva. Pri uporabi eučbenikov jih zelo majhen delež uporablja različne možnosti (približevanje strani, povečevanje besedila in slikovnega gradiva, možnosti podčrtovanja, obkroževanja, označevanja, barvanja idr.), ki jih ti učbeniki ponujajo. Predvidevamo, da se je s spremembo učnega okolja spremenil tudi delež učiteljev, ki uporabljajo e-učbenike, in zelo razširile možnosti njihove uporabe.

Uporabo e-pošte za komunikacijo z učenci je navedlo deset $(8,20 \%)$ učiteljev. Preko nje so učencem pošiljali povezave, predstavitve, ostalo učno snov in preverjanja znanja. Šest $(4,92 \%)$ učiteljev je navedlo, da so učencem dali navodilo, da se sami zvočno in vizualno posnamejo (ples, pesmi ter igranje na inštrumente) ter jim posredujejo posnetke. Preko spletnih aplikacij za kvize so znanje učencem posredovali štirje učitelji $(3,28 \%)$, dva (1,64\%) pa sta za posredovanje znanj uporabila »sistem za karaoke«.

Učitelji so skozi svoje odgovore našteli več različnih načinov, s pomočjo katerih so se lotevali poučevanja na daljavo. Večina je pri razlogih za izbiro določenega načina navedla možnost dvostranske pa tudi takojšnje komunikacije $z$ učenci. Izpostavili so tudi mnenje, da ne glede na to, kateri način poučevanja na daljavo so ubrali, učenci skozenj niso dobili toliko, kot bi dobili z izvedbo »klasičnega« pouka v učilnici. Dodali so še, da so se trudili po najboljših močeh, a se zavedajo, da so učencem zmožni dati več in da jim bodo, če se poučevanje na daljavo ponovi, več tudi dali. Žal pa je bil čas za prilagoditev izvedbe pouka v marcu 2020 zelo kratek.

Ne glede na vse prej našteto pa je seveda pomembno poudariti, da so učitelji za potrebe poučevanja na daljavo uporabili različno IKT, kar je največkrat pomenilo kombinacijo interneta in osebnega računalnika, učenci pa so pri uporabi lahko posegli tudi po drugih oblikah IKT (pametni telefon, tablični računalnik idr.). Po Mosbrukerju (2007) je najpomembnejši korak pri pripravi na samo poučevanje ravno izbira sredstva za poučevanje na daljavo. Po drugi strani Lapijeva (2020) ugotavlja, da je individualno delo učencev prevladujoča oblika dela pri poučevanju na daljavo. Nekateri učitelji so pokazali, da vsaj pri predmetu glasbena umetnost delo na daljavo ne more biti osnovano le na individualnem delu učencev. Povedali so, da veliko delajo skupaj $z$ učenci ali pa delajo zanje $v$ ločenem času ter da se tudi sami $v$ veliki meri angažirajo, saj so mnenja, da prave rezultate lahko prinese le tak način dela, če želijo doseči predvidene učne cilje.

\section{Sklepne ugotovitve}

Sprememba učnega okolja s pomočjo IKT spomladi 2020 je večino učiteljev ujela nepripravljeno, kar je za seboj potegnilo veliko težav, ki so jih učitelji 
zaznali zelo različno. Največ učiteljev je opazilo, da je bila tako njihova prilagojenost kot tudi prilagojenost učencev novemu učnemu okolju premo sorazmerna s pretečenim časom.

Povsem obratno so zaznali motivacijo učencev, za katero so mnenja, da je s pretekom časa strmo padala. S spremembo učnega okolja so se pokazale razlike tako $v$ IKT-pismenosti učiteljev kot tudi v možnosti učencev za dostop do IKT-opreme. Učitelji so pri svojem delu zaznali manjšo mero ustvarjalnosti pri pripravi učnih gradiv, kar so pripisali izčrpanosti zaradi večje porabe časa pri pripravi le-teh. $V$ povezavi s predpripravljenimi e-gradivi so omenili še, da ta niso namenjena delu na daljavo, kar je njihovo uporabo otežilo, še posebej pri predmetih, kjer učenci poleg znanj pridobivajo tudi različne spretnosti in sposobnosti.

Pri poučevanju glasbene umetnosti so različni učitelji uporabili zelo različne pristope. Tako je $v$ naši raziskavi 54 sodelujočih po združitvi njihovih odgovorov $v$ skupine po skupnih imenovalcih naštelo kar 11 različnih načinov poučevanja, vse pa so tudi podrobneje predstavili v daljših odgovorih. Najpogostejši način poučevanja je bil snemanje zvočnih in videoposnetkov $\mathrm{s}$ strani učiteljev $\mathrm{v}$ njihovih domačih okoljih, le-te pa so nato na različne načine posredovali učencem. Takoj za tem so učitelji izpostavili uporabo neavtorskih videoposnetkov na kanalih za pretočne video vsebine (YouTube, Vimeo ...). Velika večina jih je uporabljala tudi različne videokonferenčne sisteme, preko katerih so komunicirali z učenci. Za dostavo gradiv slednjim so uporabljali različne spletne učilnice ali e-pošto. Različna neavtorska gradiva, kot so zvočni in videoposnetki, so pridobili v e-učbeniških kompletih različnih slovenskih založb, nekateri pa so vsebine glasbene umetnosti podajali skozi kvize. Dva učitelja sta navedla najredkejši način poučevanja glasbene umetnosti na daljavo, in sicer $z$ uporabo "sistema za karaoke«.

Za izboljšanje poučevanja na daljavo ob uporabi IKT bi bilo potrebno razmisliti o spremembah in posodobitvah učnega načrta glasbene umetnosti, $v$ katerem bi bilo potrebno zapisati nove oblike in metode dela, predvideti in omogočiti inovativna ter interaktivna digitalna učna okolja in nenazadnje tudi priporočila za smiselno uporabo sodobne IKT ter svetovnega spleta pri poučevanju glasbene umetnosti, kar ugotavljajo tudi drugi strokovnjaki (Manches in Plowman 2017).

Predvsem zaradi specifičnosti predmeta glasbena umetnost in nezmožnosti izvajanja vseh $v$ učnem načrtu predvidenih glasbenih dejavnosti pri delu na daljavo bi bilo za izboljšanje poučevanja na daljavo potrebno učitelje poučiti o široki možnosti uporabe strokovnih interaktivnih učnih gradivih s področja glasbene umetnosti ter slednja hkrati prevetriti in posodobiti tako, da bodo v koraku s časom. 
Prispevek predstavlja eno prvih raziskav dela pri predmetu glasbena umetnost $v$ prvem in drugem vzgojno-izobraževalnem obdobju osnovne šole ob spremembi učnega okolja $v$ času prve epidemije koronavirusne bolezni (covid-19) leta 2020 v Republiki Sloveniji in zainteresiranim bralcem ponuja prvi vpogled $v$ opažanja učiteljev o prehodu iz šolskega v domače učno okolje ter načinih poučevanja predmeta glasbena umetnost na daljavo.

\section{Literatura}

Arnes. B. I. »Podatki o programu COVID19-IKT za VIZ.« http://www.arnes.si/ covid19_ikt-za-viz/.

Bečaj, J. 2008. »Avtonomija: nova razporeditev moči in odgovornosti.« Predstavitev na posvetu Fleksibilni predmetnik - pot do večje avtonomije, strokovne odgovornosti in kakovosti vzgojno-izobraževalnega dela, Olimje, Slovenija.

Borota, B. 2013. Glasbene dejavnosti in vsebine. Koper: Annales.

Craig, R. J., in J. H. Amernic. 2006. »PowerPoint Presentation Technology and the Dynamics of Teaching. «Inovative Higher Education 31 (3): 147-160.

Denac, O. 2002. Glasba pri celostnem razvoju otrokove osebnosti: priročnik za vzgojitelje, razredne učitelje, učitelje glasbe in glasbenih predmetov v splošnih in glasbenih šolah. Ljubljana: Zavod Republike Slovenije za šolstvo.

Dumont, H., D. Istance in F. Benavides, ur. 2013. Onaravi učenja: uporaba raziskav za navdih prakse. Ljubljana: Zavod Republike Slovenije za šolstvo.

Grabner, E. 2011. »Videokonference - uporaba med študentsko populacijo.« Diplomsko delo, Univerza v Mariboru.

Holden, H., in S. Button. 2006. »The Teaching of Music in the Primary School by the Non-Music Specialist." The British Journal of Music Education 23 (1): 23-38.

Javrh, P., E. Možina, K. Bider, K. Kragelj, D. Volčjak, G. Sepaher in L. Gjerek. 2018. Digitalna pismenost:opisniki temeljne zmožnosti. Ur. Petra Javrh. Na poti do življenjske uspešnosti. Ljubljana: Andragoški center Slovenije.

Jekovec, L. 2011. »Glasbene dejavnosti na osnovni šoli pod vodstvom učitelja razrednega pouka.« Diplomsko delo, Univerza v Ljubljani.

Jenko, M. 2019. »Povezanost aktivnosti staršev z aktivnostjo njihovih otrok v pevskih zborih.« Diplomsko delo, Univerza na Primorskem.

Jenko, M., in J. Kočevar. 2019. »Študirati skozi Moodle.« Predstavitev na konferenci Lastovke UP 2019: inovativno s tehnologijo do znanja, Portorož, Slovenija, 8. marec.

Keegan, D. 1996. Foundations of Distance Education. 3. izd. Routledge Studies in Distance Education. London in New York: Routledge.

Kerndl, M. 2010. »Učno okolje, ki omogoča kakovostno samostojno učenje.«Revija za elementarno izobraževanje 3 (2-3): 105-119.

Krajnc, A. 1982. Motivacija za izobraževanje. Ljubljana: Delavska enotnost. 
Kranjc, T., A. Drolc, Š. Nose Pogačnik, M. Pevec, B. Slivar, J. Uranjek in M. Weilguny. 2019. Varno in spodbudno učno okolje. Ur. M. Brejc in K. Širok. Kakovost v vrtcih in šolah 4. Ljubljana: Šola za ravnatelje.

Lapi, M. 2020. »Vpliv izobraževanja na daljavo na slovenske srednješolce.« Magistrsko delo, Univerza v Mariboru.

Lesjak, D., V. Sulčič in N. Trunk Širca. 2005. »IKT v slovenskih zavodih terciarnega izobraževanja.«V Informatika kot temeljpovezovanja:zbornikposvetovanja, ur. S. Novakovič, 666-671. Ljubljana: Slovensko društvo Informatika.

Loewus, L. 2021. »What Is Digital Literacy?« EducationWeek. https://www .edweek.org/teaching-learning/what-is-digital-literacy/2016/11.

Manches A., in L. Plowman. 2017. »Computing Education in Children's Early Years: A Call for Debate.« British Journal of Educational Technology 48 (1): 191201.

Marentič Požarnik, B. 2020. Psihologija učenja in pouka: od poučevanja k učenju. Ljubljana: Državna založba Slovenije.

Marjanovič Umek, L. 2004. Razvojna psihologija. Ljubljana: Znanstvenoraziskovalni inštitut Filozofske fakultete.

Mekić, D. 2006. »|zobraževanje na daljavo.« Diplomsko delo, Univerza v Ljubljani.

Ministrstvo za izobraževanje, znanost in šport. 2020. »Priporočila osnovnim in srednjim šolam za izvajanje izobraževanja na daljavo."

Ministrstvo za šolstvo in šport. 2011. Program osnovna šola: glasbena vzgoja; učni načrt. Ljubljana: Ministrstvo za šolstvo in šport in Zavod Republike Slovenije za šolstvo.

Moore, M. G., in G. Kearsley. 2012. Distance Education: A Systems View of Online Learning. 3. izd. Belmont, CA: Wadsworth, Cengage Learning.

Mori, I., M. Smolko, M. Kepec in M. Pur Tretjak. 2003. Glasba v prvem vzgojnoizobraževalnem obdobju osnovne šole: priročnik za učitelje, učiteljice in vzgojiteljice. Ljubljana: Zavod Republike Slovenije za šolstvo.

Mosbruker, M. 2007. »Študija primera izvedbe in evalvacije pouka z uporabo sodobne informacijsko-komunikacijske tehnologija." Sodobna pedagogika 58 (3): 220-236.

Odredba o razglasitvi epidemije nalezljive bolezni SARS-CoV-2 (COVID-19) na območju Republike Slovenije. 2020. Uradni list Republike Slovenije, št. 19. https://www.uradni-list.si/1/objava.jsp?sop=2020-01-0532.

Pesek, A. 1997. Otroci v svetu glasbe: izbrana poglavja iz glasbene psihologije in pedagogike. Ljubljana: Mladinska knjiga.

Plazar, S. 2010. »Uporaba računalnika med vzgojitelji in učitelji prvega triletja pri obravnavi družboslovnih vsebin.« Revija za elementarno izobraževanje $3(2-3): 33-46$.

Sicherl Kafol, B. 2015. Izbrana poglavja iz glasbene didaktike. Ljubljana: Pedagoška fakulteta. 
Sklep o ukrepih za nemoteno opravljanje vzgojno-izobraževalnega dela v osnovnih šolah v šolskem letu 2019/2020. 2020. Uradni list Republike Slovenije, št. 182. https://www.uradni-list.si/1/objava.jsp?sop=2020-01-3201.

Slosar, M. 1997. »Dejavniki uspešnosti razrednih učiteljev pri glasbeni vzgoji na razredni stopnji osnovne šole ali zakaj ponovna uvedba preizkusa glasbenih sposobnosti ob vpisu na Oddelek za razredni pouk." V Izobraževanje učiteljev ob vstopu v tretje tisočletje: stanje, potrebe, rešitve; zbornik prispevkov, ur. K. Destovnik in I. Matovič, 233-241. Ljubljana: Univerza v Ljubljani, Pedagoška fakulteta.

Statistični urad Republike Slovenije. 2017. »Spolna sestava učiteljev v osnovnih šolah.« https://www.stat.si/StatWeb/news/Index/6940\%oA.

B. I. »Kakovost življenja.« https://www.stat.si/StatWeb/Field/Index/10.

Toselli, L. 2020. La didattica a distanza: funziona, se sai come farla. Milano: Edizioni Sonda.

Uršič, N., in T. Lotrič. 2020. »Pouk na daljavo: nekateri primorski osnovnošolci še vedno brez računalnikov.« Radio Koper, 6. november. https://www.rtvslo .si/radiokoper/novice/pouk-na-daljavo-nekateri-primorski-osnovnosolci -se-vedno-brez-racunalnikov/541415.

Vamberger, T. 2020. »Mnenja in odzivi učencev v osnovni šoli o delu na daljavo." $\checkmark$ 1oth International Conference EDUvision 2020: Challenges and New Opportunities of Distance Learning, ur. M. Orel, J. Brala-Mudrovčić in J. Miletić, 6075. Ljubljana: EDUvision.

Vraber Jagodic, J. 2017. »Mnenje osnovnošolskih učiteljev naravoslovnih predmetov o elektronskih in interaktivnih učbenikov.« Magistrsko delo, Univerza v Ljubljani.

Žugič Perić, M. 2020. »lzkušnja z izobraževanjem na daljavo v 1. razredu osnovne šole.« Sodobna pedagogika 71 (4): 126-137.

\section{Adaptation of Teachers in Teaching Music Art with the Change of Learning Environment in Spring 2020}

Since March 2020, the world has changed a lot in many ways. Now, more often than ever before, we work, educate, etc. over the internet. The learning environment of both teachers and students was instantly changed. Distance music teaching in the 1st and 2nd primary school cycle during the coronavirus disease 2019 (COVID-19) epidemic became reality. The specificity of the subject is mainly represented by musical activities and, through their implementation in classrooms, the acquisition of both musical knowledge and abilities and skills. While doing research for the article, we were interested in how teachers who teach music in the 1st and 2nd primary school cycle saw the transition from the learning environment in the classroom to the learning environment of the student's and teacher's home with the help of ICT and how their work, due to the specifics of music art (listening, performing, and creating) has changed. 
We found out that the transition from school to a home learning environment caught many teachers unprepared, which led to many problems that teachers recognized very differently. They also had to adapt their way of teaching music to the changed situation.

Keywords: music, musical activities, distant teaching, changing the learning environment, ICT 